\title{
Current knowledge and perspectives of potential impacts of Salmonella enterica on the profile of the gut microbiota
}

\author{
Nesreen H. Aljahdali, ${ }^{1,2}$, Yasser M. Sanad ${ }^{1,3,4}$, Jing $\operatorname{Han}^{1}$ and Steven L. Foley ${ }^{1 *}$ (D)
}

\begin{abstract}
In the past decade, the initial studies of the gut microbiota started focusing on the correlation of the composition of the gut microbiota and the health or diseases of the host, and there are extensive literature reviews pertaining to this theme. However, little is known about the association between the microbiota, the host, and pathogenic bacteria, such as Salmonella enterica, which is among the most important foodborne pathogens and identified as the source of multiple outbreaks linked to contaminated foods causing salmonellosis. Secretion systems, flagella, fimbriae, endotoxins, and exotoxins are factors that play the most important roles in the successful infection of the host cell by Salmonella. Infections with S. enterica, which is a threat to human health, can alter the genomic, taxonomic, and functional traits of the gut microbiota. The purpose of this review is to outline the state of knowledge on the impacts of S. enterica on the intestinal microbiota and highlight the need to identify the gut bacteria that could contribute to salmonellosis.
\end{abstract}

Keywords: Gut microbiota, Salmonella enterica, Host cell-micbobe interaction

\section{Background}

An enteric pathogen is a microbe that impacts the gastrointestinal tract (GIT) and causes gastrointestinal diseases. These infectious pathogens, including bacteria such as Escherichia, Campylobacter, Shigella, Yersinia, Salmonella, and other genera, protozoa such as amoeba, rotavirus, and other pathogenic microorganisms, are responsible for causing gastroenteritis [1]. Among enteric pathogens there is often an age-associated bias with the development of gastroenteritis upon exposure. For example, Escherichia coli (E. coli) causes enteric disease in people most commonly during early and late ages, whereas rotaviruses are the most common among infants and young children. Similarly, Campylobacter infections occur most often in early childhood into young

\footnotetext{
* Correspondence: steven.foley@fda.hhs.gov

'Division of Microbiology, National Center for Toxicological Research, U.S. Food and Drug Administration, 3900 NCTR Rd, Jefferson, AR 72079, USA Full list of author information is available at the end of the article
}

adulthood, while Salmonella infections have higher rates in infants and people over 65 [2]. Salmonella infections are a significant global public health threat and contribute to morbidity and mortality worldwide [3]. The Salmonella genus is generally considered to be divided into two species: S. enterica and S. bongori. Although, S. bongori appears adapted to cold-blooded animals, it can infect humans, but accounts for less than $1 \%$ of human infections $[4,5]$. On the other hand, several of the subspecies of $S$. enterica are more commonly isolated from warm-blooded animals. S. enterica includes six subspecies: S. enterica subsp. enterica, S. enterica subsp. salamae, S. enterica subsp. arizonae, S. enterica subsp. diarizonae, S. enterica subsp. houtenae, and S. enterica subsp. indica. Among these subspecies, S. enterica subsp. salamae, and S. enterica subsp. arizonae, are more commonly isolated from cold-blooded animals $[6,7] . S$. enterica includes more than 2600 serotypes that differ from each other based on the polysaccharide portion of 
lipopolysaccharide layer ( $\mathrm{O}$ antigen) and/or the filamentous portion of the flagella ( $\mathrm{H}$ antigen) [8]. Scallan et al (2011) estimated that nontyphoidal Salmonella account for approximately $28 \%$ of foodborne illness-associated deaths [9]. The predominant subspecies associated with severe disease is $S$. enterica subsp. enterica and among its serotypes, there is also variability in the outcomes of disease with some serovars causing relatively severe outcomes. For example, S. enterica serovar Heidelberg contributes to about $7 \%$ of the Salmonella-related deaths in the U.S. [10] and $11 \%$ of reported invasive infections, which are relatively high percentages considering that they typically cause under $5 \%$ of infections [11].

S. enterica is a highly diverse Gram-negative bacterial species that can be divided into typhoidal and nontyphoidal Salmonella serovars. Typhoidal Salmonella serovars share virulence properties that were obtained through convergent evolution and therefore these virulence genes are absent from most non-typhoidal Salmonella serovars [12]. For instance, $S$. Typhi has specific virulence factors, including typhoid toxin and $\mathrm{Vi}$ antigen $[7,12,13]$. Nontyphoidal $S$. including Typhimurium, Enteritidis, Heidelberg, Newport, Weltevreden, Choleraesuis, Saintpaul, Infantis and Javiana cause gastroenteritis, while typhoidal S. including Typhi and Paratyphi serovars commonly cause typhoid fever [13]. Nontyphoidal serotypes can be transferred between humans and animals, whereas typhoidal serotypes are only transmissible among humans [14]. Notably, nontyphoidal Salmonella disseminates rapidly in people with an impaired immune system and in neonates [15]. Ninety-five percent of $S$. enterica infections are associated with consumption of contaminated food products [7]. More than 2600 serotypes of Salmonella have been identified [16, 17]. To clarify links between Salmonella serotypes and food products, Jackson and colleagues (2013) indicated that more than $80 \%$ of outbreaks caused by serotypes Enteritidis, Heidelberg, and Hadar were associated with eggs or poultry, while greater than $50 \%$ of outbreaks caused by serotypes Javiana, Litchfield, Mbandaka, Muenchen, Poona, and Senftenberg were attributed to plant commodities. Serotypes Typhimurium and Newport were linked to a wide variety of food commodities [18]. These organisms invade the GIT causing salmonellosis, which is typically characterized by a self-limiting gastroenteritis symptom, such as diarrhea, fever, abdominal cramps, and vomiting [19].

The GIT is host to diverse taxa from across the tree of life, such as bacteria, archaea, fungi, protozoa, and viruses that make up the gut microbiota [20]. The gut harbors a highly diverse microbial community, which impacts the host's nutrition, physiology, and immune system [21, 22]. The composition of the gut microbiota remains relatively stable within healthy people throughout their lifetime
[23]. However, specific shifts in the composition and diversity have been linked to diet, diseases, and susceptibility to infection. For instance, alteration of the intestinal microbiota has been associated with acute inflammation that can be triggered by enteric pathogens [24]. Salmonella and other pathogens have been widely studied; however, the interactions between enteric pathogens and intestinal microbes are not well understood. In this review we will summarize the knowledge of the interaction between Salmonella and intestinal microbiota that is currently available and clarify the research that needs to be undertaken to understand the consequences of theses interactions.

\section{Gut microbiota}

\section{Human gut microbiota/microbiome}

The human body hosts up to 100 trillion $\left(10^{14}\right) \mathrm{mi}-$ crobes, with the majority residing in the GIT, which has become the most investigated microbial community in recent years [20,25]. Most of the microbiota in the GIT are primarily anaerobic bacteria. Typically, $97 \%$ of the bacteria in the GIT are strict anaerobes, and only 3\% constitute the aerobic bacteria (facultative anaerobes) [26]. The collective pan-genome of bacterial cells is larger than the human genome [25]. There are large differences in microbial load in different regions of the GIT. To illustrate this, Helicobacter pylori resides in the stomach at a concentration of $10^{2}-10^{3}$ cells $/ \mathrm{ml}$. The mucosa of the small intestine is dominated by the phyla Bacteroidetes and members of the Clostridiales cluster XIV and IV, and the lumen contains members of the Enterobacteriaceae with a biomass of $10^{4}-10^{5} \mathrm{cell} / \mathrm{ml}[22,25]$. The large intestine contains species from the phyla Bacteroidetes and Firmicutes with amounts in the range of $10^{11}-10^{12}$, with other phyla including Proteobacteria, Verrucomicrobia, and Actinobacteria being less represented (Fig. 1) [22, 25].

Generally, the composition of the gut microbiota shifts throughout life as people transition from newborns to infants to young adults to elders. The GIT of newborns is expected to be sterile at birth. However, major shifts take place during and immediately after birth due to the colonization with aerobic bacteria (Enterococcaceae and Streptococcus) [27]. The gut microbiota composition of infants is highly dynamic with low levels of total bacteria [28]. The microbiota of infants is dominated by some members of Clostridium, Bifidobacteria, and facultative anaerobes like $E$. coli, while elderly people generally have higher levels of Bacteroidetes and facultative anaerobes like E. coli [29]. In young adults the composition of the gut microbiota is dominated by Bacteroidetes and Firmicutes with smaller portions of Actinobacteria, Verrucomicrobia, and Proteobacteria [25]. 


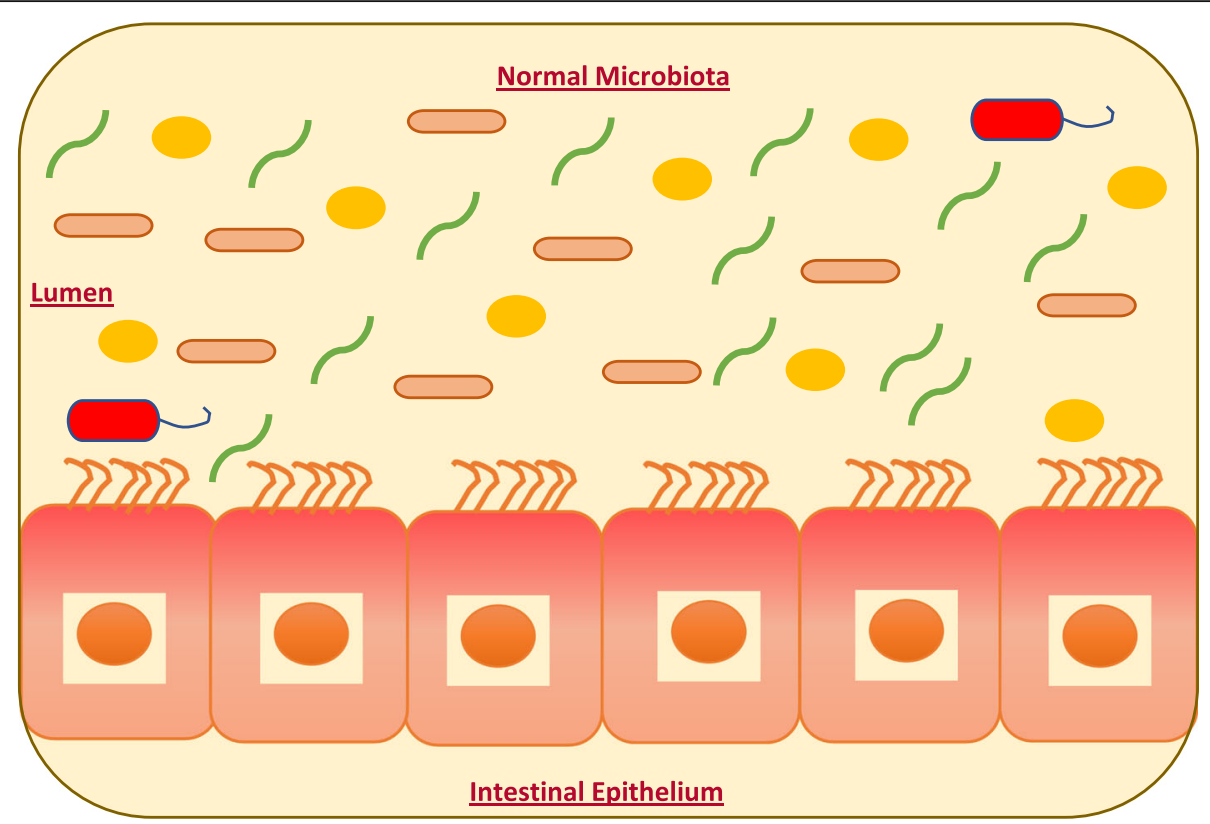

Fig. 1 Normal gastrointestinal tract of humans harbors the high relative abundance of commensal bacteria, such as Bacteroidetes and Firmicutes with smaller portions of Actinobacteria, Verrucomicrobia, and Proteobacteria

A generally symbiotic relationship between the host and the gut microbiota has been known to be strongly associated with health [22]. The host provides a nutrient-rich and hospitable environment for the gut microbiota. In parallel, the gut microbiota is extremely important as it supports the host by enhancing metabolism, maturation of the immune system, developing the GIT, and protecting against pathogens $[26,30]$. Also, intestinal bacteria degrade undigested foods by two main metabolic pathways: saccharolytic and proteolytic pathways. Non-digestible carbohydrates are degraded into monomeric sugars that can be converted to beneficial products, such as shortchain fatty acids (SCFAs), principally acetate, propionate, and butyrate. These products have been shown to decrease the risk of developing gastrointestinal disorders, cancer, and other metabolic syndromes [31-33]. Peptide and amino acids, on the other hand, are hydrolyzed into short or branched-chain fatty acids and other metabolic elements, some of which are possibly toxic to the host, such as uremic toxins $[34,35]$. The gut microbiota usually lives within the host in a commensal manner; however, many external factors can alter the balance of this microbiota composition, potentially leading to gastrointestinal diseases, such as salmonellosis.

\section{Salmonellosis}

\section{Salmonella gastroenteritis}

Salmonella infections are significant economic and public health concerns, costing an estimated 3.7 billion dollars per year [36, 37]. According to the Centers for Diseases
Control and Prevention (CDC), it is estimated that members of the Salmonella genus cause 1.35 million infections leading to 26,500 hospitalizations and 420 deaths per year in the United States [38]. Salmonellosis can manifest in several disease syndromes including Salmonella gastroenteritis, inflammation, enteric fever, bacterium, and other syndromes $[39,40]$. Salmonella gastroenteritis is the predominant form of salmonellosis and is characterized by stomach cramps, diarrhea, fever, and sometimes vomiting [3]. Human salmonellosis is most commonly associated with consumption of contaminated foods, resulting in the ability of Salmonella to colonize and persist in the GIT [7, 41-43]. It has been reported that the highest hospitalization rates are among the elderly and young children $[38,44]$. As previously mentioned, the gut microbiota composition of infants and old people are highly dynamic with higher percentages of facultative anaerobes like $E$. coli [29]. Thus, the ability of Salmonella to invade the GIT is relatively high when the bacterial population of the GIT is less stable due to higher levels of Proteobacteria [2]. Furthermore, young children have immune systems that are still developing (immunocompromised) that also contributed to their higher prevalence of salmonellosis compared to adults [45]. Details of the interactions of Salmonella and the GIT will be explored in greater detail throughout the review.

The plasticity of bacterial genomes is known in Salmonella species to influence the acquisition of genes through horizontal and vertical gene transfer [46]. This plasticity can be achieved with the presence of mobile 
genetic elements (MGEs), such as plasmids [11]. Plasmids play vital roles in the ability of Salmonella to survive in different food animal sources and cause infections in humans [9]. Plasmids are self-replicating genetic elements that can allow for gene transfer between different bacteria. The presence of plasmids can impact the ability of $S$. enterica to cause disease and avoid treatment strategies due to the presence of antimicrobial resistance and virulence genes that they carry. These factors have allowed for the dissemination of epidemic clones over large geographical distances that have contributed to significant morbidity and mortality [47, 48]. Several plasmid types have been identified carrying antimicrobial resistance and virulence genes [7]. Horizontal gene transfer, with plasmids or other MGEs, can impact the host range of the bacterium [7]. The acquisition of genes can be important for colonization of pathogens in the host cell. S. enterica and other pathogens can enter the host's GIT through the fecal-oral route, and the effector proteins they harbor can manipulate and overcome the intestinal epithelial barrier [49]. The ability of Salmonella and other enteric pathogens to invade the GIT is relatively high when the colonic microbiota is less stable due to higher numbers of Proteobacteria during infections [2]. Despite the role of the intestinal epithelium as a protective barrier against bacterial infections, the genetics of Salmonella itself play a significant role in survival and growth in diversified host environments $[7,50]$. Several strategies allow $S$. enterica to effectively compete with the gut microbiota and overcome colonization, such as the expression of an assortment of virulence factors and the exploitation of intestinal inflammatory processes.

S. enterica harbor the Salmonella pathogenicity island1 (SPI-1) encoded type III secretion system (T3SS) and Salmonella pathogenicity island-2 (SPI-2) encoded T3SS, which facilitate the attachment, invasion, and internalization of Salmonella during infection in the host cell. To illustrate, $S$. Typhimurium contains genes, such as those for the Salmonella invasive proteins (Sips) and Salmonella outer proteins (Sops) encoded in the SPI-1 T3SS. These proteins alter the actin cytoskeleton of intestinal epithelial cells, resulting in membrane ruffling and bacterial internalization [51]. Furthermore, SopE induces nitrate production by the host, which boosts Salmonella growth in the host cell [52]. Once Salmonella is engulfed within intestinal epithelial cells, the host cell membrane is rearranged leading to the formation of a membrane-bound organelle termed a Salmonella containing vacuole $(\mathrm{SCV})$, where Salmonella can replicate to high numbers before exiting the cell and infecting new host cells [53]. The SPI-2 T3SS genes are expressed inside the SCV, resulting in the rapid induction of intestinal inflammation [54]. In addition to SPIs, plasmids, carrying virulence genes, are essential for the infection process to host cells in order to ensure nutrient supply [55], compete against commensal bacteria [56], avoid killing by innate immune system, and manipulate the host to establish infection [57].

\section{Inflammatory response}

The innate immune system plays a crucial role in controlling infections when Salmonella has been detected. To illustrate, the O-antigen and lipid A of Salmonella are detected by the innate immune system elements including complement component 3 and macrophages, which result in the production of proinflammatory cytokines, such as IL-22, IL-18, TNF- $\alpha$, and other cytokines [58]. Thereby, the induction of cytokines culminates the host defense pathway, including neutrophil recruitment, macrophage activation, and the release of an antimicrobial protein [24]. Cattle infected with $S$. Typhimurium displayed a massive infiltration of neutrophils following infection [59]. Neutrophils limit pathogen loads in the mucosa and in the intestinal lumen at later stages of infection [60]. Macrophages also contribute to pathogen clearance; for instance, proteins called toll-like receptors (TLRs) on the surface of macrophages can recognize pathogen-associated molecular patterns (PAMPs) and eliminate the pathogens [61]. Moreover, macrophages produce nitric oxide (NO), which diffuses across cellular membranes to combat pathogens [62]. Additionally, during $S$. Typhimurium infection, IL-18 plays a vital for induction of inflammation within the first 12 $\mathrm{h}$ of infection and recruits neutrophil and mature natural killer (NK) cells to the site of infection. The NK cells express perforin, which plays a major role in the induction of mucosal inflammation [63]. This inflammation plays important roles in the pathogenesis of Salmonella in the GIT.

Microbial communities play a fundamental role in regulating immunity in the GIT [22]. The intestinal microbiota mediates colonization resistance against enteric pathogens through activation of antimicrobial host immune mechanisms. For instance, Lactobacillus reuteri plays an important role in the induction of IL22, a cytokine that enhances the mucosal barrier against pathogens $[58,64]$. Another important support of the immune response modulated by the microbiota involves the stimulation of $\mathrm{IL}-1 \mathrm{~B}$, which results in the recruitment of neutrophils to the site of the infection [65]. However, infections with Salmonella result from competition with the gut microbiota during an intestinal inflammatory response [66]. To illustrate this phenomenon, during a $S$. Typhimurium infection, neutrophils that migrate into the lumen of the colon release reactive oxygen species (ROS), which oxidizes 
thiosulfate to form tetrathionate that can be used by $S$. Typhimurium as an anaerobic respiratory electron acceptor allowing for competition with the microbiota $[24,67]$. Moreover, NO, which is produced by macrophage, can be exploited by Salmonella and used to generate nitrate, which can be used as a terminal electron acceptor [52].

The more rapid growth of $S$. Typhimurium in the intestine is due in part to its ability to utilize ethanolamine, which is released from the epithelial tissue [68]. After inflammation is induced, lipocalin-2, a host antimicrobial protein is released into the intestinal lumen in response to IL17- and IL-22 [69]. Lipocalin2 binds to enterobactin that is produced by members of the Enterobacteriaceae in the microbiome, but not salmochelin that is produced by Salmonella [70]. The sequestration of enterobactin, but not salmochelin, allows for the $S$. Typhimurium to bloom in the lumen of the inflamed intestine and result in a bacteriostatic activity for some commensal bacteria, such as E. coli [70, 71]. Additionally, S. Typhimurium induces expression of colicin Ib and Ia genes, which increase the fitness of $S$. Typhimurium in competition against commensal E. coli [21]. Thus, Salmonella elicits an acute intestinal inflammatory response from the host, which enhances its transmission and growth in the GIT. Once the Salmonella has colonized the GIT, the alteration of the gut microbiota composition and the horizontal gene transfer (HGT) between Salmonella and commensal bacteria can occur (Fig. 2).

\section{Interaction between gut microbes and Salmonella} Alteration microbial composition in the gut caused by $S$. enterica

The number of Enterobacteriaceae is relatively low when the gut microbiota has developmentally stabilized in the GIT [25]. The microbiol communities produce a diversity of products, such as SCFAs, secondary bile acids, and bacteriocins that provide resistance against colonization by pathogens in the GIT. The commensal microbiota protects the host from enteric pathogens [72]. For example, in an in vivo study, microcin, produced by $E$. coli Nissle $(\mathrm{EcN})$, can limit the growth of competing Enterobacteriaceae, including commensal $E$. coli, and pathogenic Salmonella in the inflamed gut [73]. Conversely, infections with Salmonella can impact the host intestinal microbial composition (Table 1). A recent study found that infections with $S$. Typhimurium resulted in the alteration of the gut microbiota composition in the ceca of pigs. There were significant increases in the population of Anaerobacter, Barnesiella, Pediococcus, Sporacetigenium, Turicibacter, Catenibacterium, Prevotella, Pseudobutyrivibrio, and Xylanibacter in the infected pigs compared to the control groups [74]. Furthermore, in an in vivo setting, $S$. Typhimurium infections in pigs impacted the microbial diversity at the ileum mucous. This change was reflected in a rise in numbers of the potentially pathogenic bacteria Citrobacter, with a corresponding decrease in Bifidobacterium, Lactobacillus, and Ruminococcus, which are often considered beneficial to gut health [75]. Moreover, it was

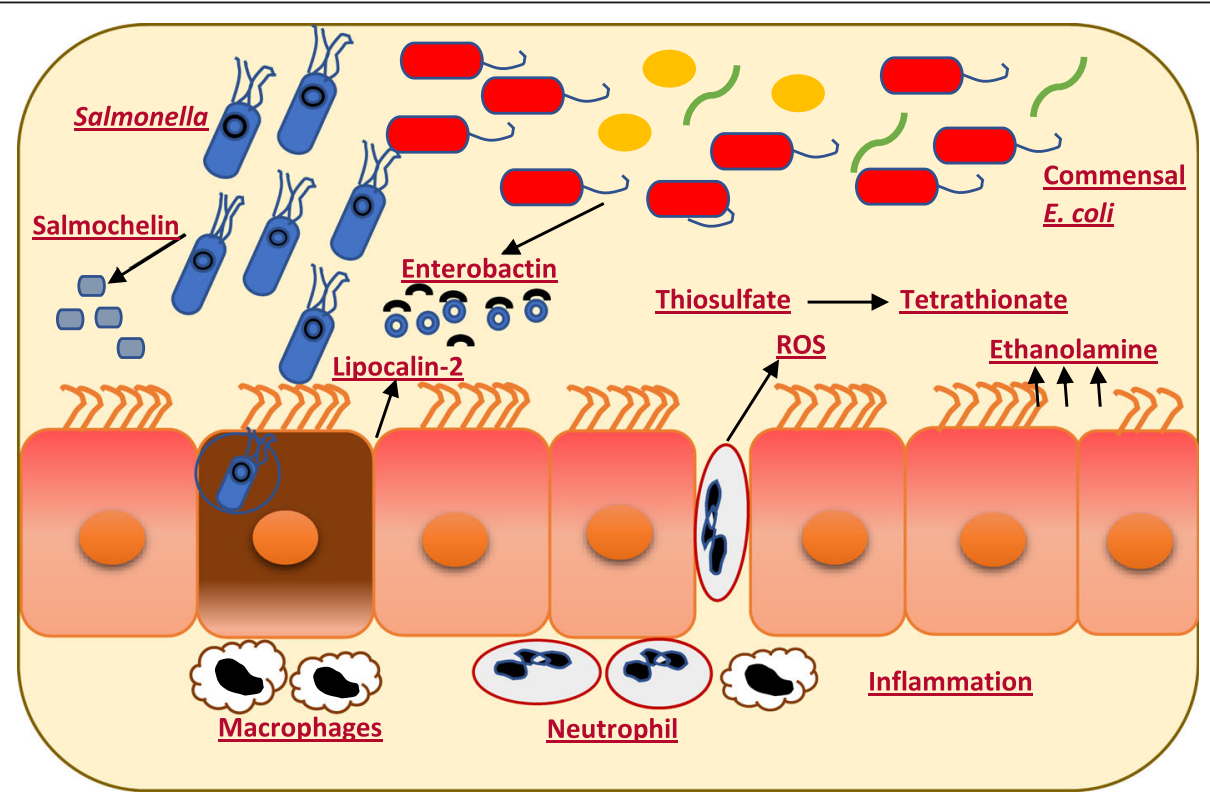

Fig. 2 During infection with Salmonella, the gut shifts to the low relative abundance of commensal bacteria such as, Lachnospiraceae, Clostridiales with a higher portion of members of Enterobacteriaceae, E. coli. Neutrophils migrate and release ROS, which oxidizes thiosulfate to tetrathionate used by Salmonella. Lipocalin-2 release from the intestinal lumen and bind to enterobactin, but not salmochelin 
Table 1 Summary of the effect of S. enterica on the gut microbiota composition

\begin{tabular}{|c|c|c|c|}
\hline S. enterica & Impact of infection on gut microbiota & $\begin{array}{l}\text { Method for Analyses of Gut } \\
\text { Microbiota }\end{array}$ & Reference \\
\hline $\begin{array}{l}\text { S. Typhimurium infected } \\
\text { pig }\end{array}$ & $\begin{array}{l}\text { Increase in Anaerobacter, Barnesiella, Pediococcus, Sporacetigenium, } \\
\text { Turicibacter, Catenibacterium, Prevotella, Pseudobutyrivibrio, and Xylanibacter }\end{array}$ & Roche 454 GS-FLX sequencer & {$[74]$} \\
\hline $\begin{array}{l}\text { S. Typhimurium infected } \\
\text { pig }\end{array}$ & $\begin{array}{l}\text { Increase Citrobacter but decrease Bifidobacterium, Lactobacillus, Clostridium } \\
\text { spp., and Ruminococcus }\end{array}$ & Illumina MiSeq sequencer & {$[75]$} \\
\hline $\begin{array}{l}\text { S. Typhimurium-infected } \\
\text { mice }\end{array}$ & $\begin{array}{l}\text { Increase Enterobacteriaceae members, such as Enterobacter cancerogenus, } \\
\text { Proteus penneri, and Escherichia fergusonii }\end{array}$ & Illumina MiSeq sequencer & [77] \\
\hline $\begin{array}{l}\text { S. Typhimurium-infected } \\
\text { mice }\end{array}$ & $\begin{array}{l}\text { Decrease Lactobacillus spp., Enterococcus spp., Eubacterium rectale, and } \\
\text { Clostridium coccoides }\end{array}$ & $\begin{array}{l}\text { Quantitative real-time PCR } \\
\text { amplification }\end{array}$ & [78] \\
\hline $\begin{array}{l}\text { S. Enteritidis infected } \\
\text { chicken }\end{array}$ & $\begin{array}{l}\text { Increase Anaerotruncus, Bacillus, Enterococcus, Anaerostipes, Flavonifractor } \\
\text { and Intestinimonas but decrease Blautia, Shuttleworthia, and Anaerostipes }\end{array}$ & Illumina MiSeq sequencer & {$[79]$} \\
\hline $\begin{array}{l}\text { S. Enteritidis infected } \\
\text { young chicken }\end{array}$ & Increase Enterobacteriaceae members but decrease Lachnospiraceae family & Illumina MiSeq sequencer & {$[80]$} \\
\hline $\begin{array}{l}\text { S. Enteritidis infected } \\
\text { chicken }\end{array}$ & $\begin{array}{l}\text { Increase Enterobacteriaceae family but decrease Ruminococcaceae } \\
\text { members }\end{array}$ & Pyrosequencing 454 sequencer & {$[81]$} \\
\hline $\begin{array}{l}\text { S. Enteritidis infected } \\
\text { chicken }\end{array}$ & $\begin{array}{l}\text { Increase Enterobacteriales bacteria but decrease Clostridiales, Lactobacillales, } \\
\text { and Bifidobacteriales }\end{array}$ & $\begin{array}{l}\text { Quantitative real-time PCR } \\
\text { amplification }\end{array}$ & {$[82]$} \\
\hline
\end{tabular}

reported that infections with $S$. Typhimurium resulted in a reduction of specific microbiota species, such as SCFA-producing bacteria [76]. More recently it was found that $S$. Typhimurium-infected mice disturbed the gut microbiota composition with an increase in the relative abundance of Enterobacteriaceae, including Enterobacter cancerogenus, Proteus penneri, and Escherichia fergusonii, but an overall decrease in bacterial diversity [77]. Barman et al (2008) found that infections with $S$. Typhimurium resulted in the reduction of the total bacterial number in the cecum and large intestine of mice [78]. They found the relative abundances of Lactobacillus, Enterococcus, Eubacterium rectale, and Clostridium coccoides were significantly lower in $S$. Typhimurium infected mice compared to uninfected controls [78].

Similar findings demonstrated that $S$. Enteritidis can affect the composition of the gut microbiota by changing the relative abundance of certain microbes. It was found that chickens inoculated with $S$. Enteritidis over an extended period had an altered relative abundance of genera at different time points [79]. Blautia, Shuttleworthia, and Anaerostipes were less abundant, but Anaerotruncus, Bacillus, Enterococcus, Anaerostipes, Flavonifractor and Intestinimonas were more abundant in the infected chicken than the control group [79]. Another study found that the relative abundance and the overall diversity of the microbiota populations significantly changed at the family level after infections with $S$. Enteritidis [80]. The study demonstrated that Salmonella colonization in the GIT of the chicken had a significant inverse correlation between the Enterobacteriaceae and Lachnospiraceae families, with an increase of Enterobacteriaceae members [80]. Also, a previous report studying hatched chicks found that infection with $S$. Enteritidis caused a minor numerical increase in the members of Enterobacteriaceae, but Ruminococcaceae decreased, although these results were not significant [81]. Likewise, Juricova et al (2013) demonstrated that infections with $S$. Enteritidis can alter the number of bacteria at the order taxonomic level [82]. The relative abundance of Enterobacteriales was higher in the infected chickens than in the control group. This increase corresponded to a decline in the relative abundance of Clostridiales, Lactobacillales, and Bifidobacteriales [82] (Fig. 3). Interestingly, it is important to note that there are other pathogens that can impact the diversity and abundance of the gut microbiota. Thus, there is interest to know how other pathogenic bacteria can alter the composition of the gut bacteria. Previous studies have indicated that the intestinal communities in patients with enteric bacterial infections had lower species richness and diversity, compared to apparently healthy people [83]. For instance, patients infected with different pathogens, such as Campylobacter, Salmonella, Shiga toxin-producing E.coli (STEC), and Shigella had high abundance of Proteobacteria members, while higher abundances of Bacteroidetes and Firmicutes were observed in healthy people [83]. The study found that the relative percentage of Proteobacteria was different between the populations colonized with different pathogenic bacteria. To illustrate, the relative abundances of Proteobacteria was 37\% in patients infected with Campylobacter, followed by 29\% with Salmonella, 18\% with STEC, and 38\% with Shigella [83]. Furthermore, the authors noted that genus Escherichia predominated in the fecal microbiome of patients infected with pathogens such as Campylobacter, Salmonella, Shigella and STEC, where the mean percentage of Escherichia were 0.21, 0.14, 0.24, and 0.21, 


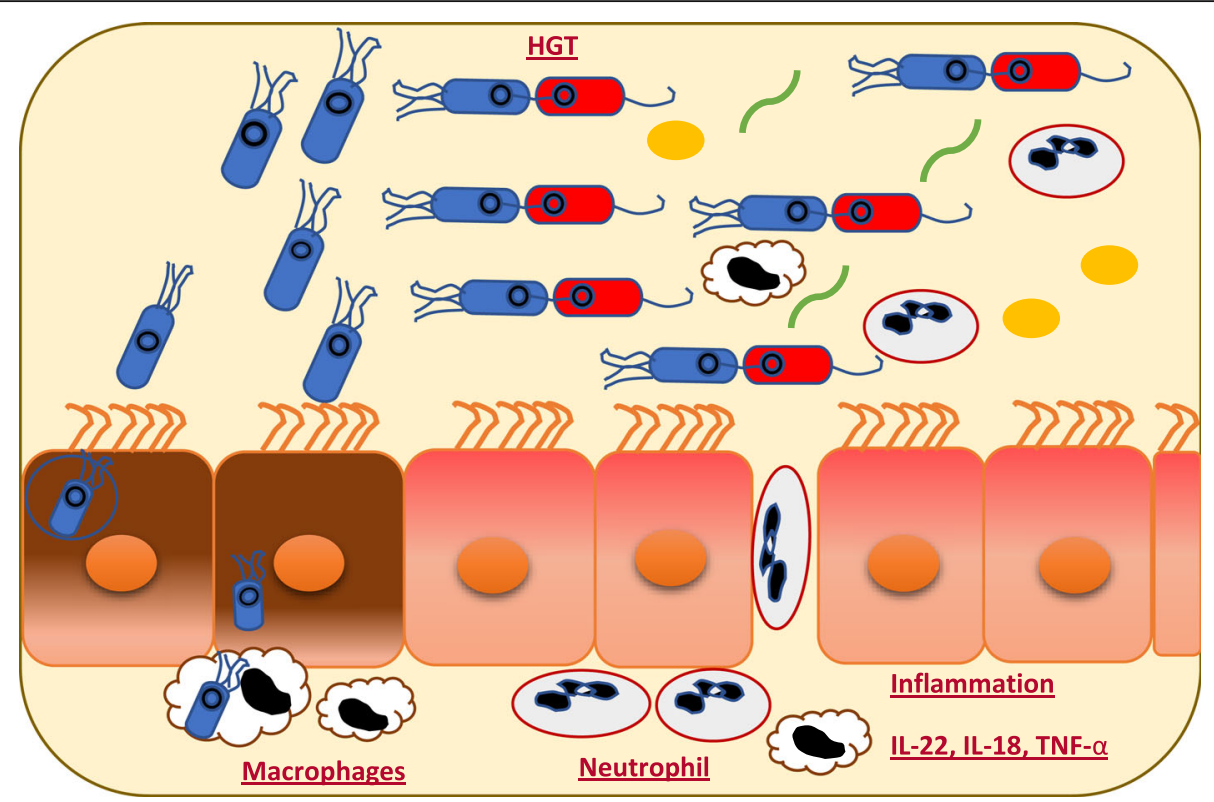

Fig. 3 During infection with Salmonella, the horizontal gene transfer (HGT) can occur between Salmonella and commensal bacteria, such as commensal E. coli

respectively, compared to uninfected people (0.01) [83]. Thus, once the alteration of the microbial profile in the GIT happens, the effective conjugative transfer can occur among bacteria [21].

\section{Horizontal gene transfer between S. enterica and commensal bacteria}

HGT or lateral gene transfer (LGT) is the exchange of genetic material between unicellular and/or multicellular organisms by means other than by the vertical transmission of genetics between generations [84]. A few recent studies have started to focus on the prevalence of antimicrobial resistance (AMR) genes in the commensal microbiota. The gut microbiota shows greater rate of HGT than that of bacteria in other environments [85]. HGT can occur via three main mechanisms: transformation, transduction or conjugation [86]. Persistent temperature, nutrient influx, and the high relative abundance of microbes in the gut form an appropriate environment for HGT among bacteria. The plasticity of microbial metagenome is believed to be attributable to HGT between microbes $[87,88]$. It has been reported that different bacteria can carry identical genes [89]. For example, a study reported that a bile salt hydrolase $(b s h)$ gene, encoding resistance to bile found in Bacteroides, Bifidobacterium, Clostridium, Lactobacillus, and Enterococcus, could be obtained by HGT [90]. The members of Enterobacteriaceae are prime examples by which conjugation-mediated HGT has occurred at a relatively high rate in the inflamed gut [21]. In normal gut, the proportion of Enterobacteriaceae is very low compared to other taxa. Thus, effective conjugative plasmid transfer is low among the Enterobacteriaceae due to the low density of donor and recipient bacteria causing a decreased rate of conjugation-mediated HGT $[21,91]$.

Although, contact-dependent conjugation between $E n$ terobacteriaceae is inhibited by commensal microbiota, the inflammatory response to pathogens can boost the frequency of conjugative HGT [21]. Infections with enteric Salmonella can cause Enterobacteriaceae to thrive, which can lead to increased HGT between $S$. enterica and commensal microbes (Table 2). Consequently, the intestinal microbiota can act as reservoir for virulence and antimicrobial resistance genes [87, 92]. Stecher and colleagues (2012) found that the colicin-plasmid p2 was able to transfer from $S$. Typhimurium to commensal $E$. coli at a high rate in an in vivo mouse colitis model [21]. Another study found that the transfer of a p3464b plasmid, which carried $b l a_{C T X-M-9}$ resistance gene, from $S$. Virchow isolated from a chicken farm to E. coli happened at a higher rate in vivo than in in vitro studies [93]. Further, Faure et al (2010) confirmed that this resistance plasmid was transferred from $S$. Virchow to a commensal $E$. coli isolated from the human GIT using a gnotobiotic mouse model [94]. A recent study demonstrated that pIFM3844 plasmid, harboring multidrug resistance genes and $b l a_{C T X-M 1}$ gene, was transferred from $S$. Typhimurium to commensal $E$. coli in an in vitro chicken gut model at a relatively high rate [95]. In early study, Aviv et al (2016) found that pESI megaplasmid, 
Table 2 Summary of horizontal gene transfer between S. enterica and commensal bacteria

\begin{tabular}{|c|c|c|}
\hline Mobile genetic elements & S. enterica & Reference \\
\hline Colicin-plasmid p2 & $\begin{array}{l}\text { From S. Typhimurium to } \\
\text { commensal E. coli. }\end{array}$ & {$[21]$} \\
\hline $\begin{array}{l}\text { p3464b plasmid carrying } \\
\text { bla }_{C T X-M-9} \text { gene. }\end{array}$ & $\begin{array}{l}\text { From S. Virchow isolated } \\
\text { from a chicken farm to E. coli. }\end{array}$ & [93] \\
\hline $\begin{array}{l}\text { Plasmid carrying bla } a_{C T X-M-9} \\
\text { gene. }\end{array}$ & $\begin{array}{l}\text { From S. Virchow originating } \\
\text { from poultry to a commensal } \\
\text { E. coli isolated from human. }\end{array}$ & [94] \\
\hline $\begin{array}{l}\text { plFM3844 plasmid carrying } \\
\text { multidrug resistance genes } \\
\text { and bla } a_{C T X-M 1} \text { gene. }\end{array}$ & $\begin{array}{l}\text { From S. Typhimurium to } \\
\text { commensal E. coli. }\end{array}$ & [95] \\
\hline $\begin{array}{l}\text { pESI megaplasmid carrying } \\
\text { multidrug resistance and } \\
\text { virulence genes. }\end{array}$ & $\begin{array}{l}\text { From S. Infantis to } \\
\text { commensal E. coli }\end{array}$ & [96] \\
\hline $\begin{array}{l}\text { pSA831R plasmid carrying } \\
\text { bla }\end{array}$ & $\begin{array}{l}\text { From members of the family } \\
\text { Enterobacteriaceae to } S \text {. } \\
\text { Anatum in the GIT of } \\
\text { patients. }\end{array}$ & {$[97]$} \\
\hline $\begin{array}{l}\text { pIPI849 plasmid carrying } \\
\text { bla TEM-3 gene. }\end{array}$ & $\begin{array}{l}\text { From Klebsiella pneumoniae } \\
\text { to S. Kedougou in the GIT of } \\
\text { individual patients. }\end{array}$ & [98] \\
\hline $\begin{array}{l}\text { 72-MDa plasmid carrying } \\
\text { blacmy-2 gene. }\end{array}$ & $\begin{array}{l}\text { From E. coli to S. Newport } \\
\text { isolated from turkey. }\end{array}$ & [99] \\
\hline $\begin{array}{l}\text { IncK2-plasmid carrying } \\
\text { bla } \text { CMY-2 gene. }^{\text {. }}\end{array}$ & $\begin{array}{l}\text { From E. coli to } S \text {. Heidelberg } \\
\text { isolated from chicken. }\end{array}$ & {$[100]$} \\
\hline $\begin{array}{l}\text { R plasmid encoded } \\
\text { resistance to streptomycin. }\end{array}$ & $\begin{array}{l}\text { From E. coli to S. Lomita in } \\
\text { the GIT of sheep. }\end{array}$ & {$[101]$} \\
\hline
\end{tabular}

carrying multidrug resistance and virulence genes, can be horizontally transferred to commensal $E$. coli of the mice gut microbiota from $S$. Infantis [96].

On the other hand, plasmid-mediated antibiotic resistance transfer may also occur in the opposite direction, from the commensal bacteria to $S$. enterica. For example, a study suggested that pSA831R plasmid carrying the bla $a_{\text {CTX-M-3 }}$ gene, encoding resistance to ceftriaxone found in $S$. Anatum, could be acquired from other members of the family Enterobacteriaceae through the exchange of genetic materials in the GIT of patients [97]. Archambaud et al (1991) found that S. Kedougou isolated from the stools and a blood culture of a patient likely acquired a plPl849 plasmid carrying $b l a_{\mathrm{TEM}-3}$ gene from Klebsiella pneumoniae in the GIT of individual patients [98]. Also, the 72-MDa plasmid containing bla $a_{\mathrm{CMY}-2}$ gene was likely transferred from E. coli to $S$. Newport present in the GIT of turkeys [99]. Another study found that $S$. Heidelberg acquired an IncK2 plasmid carrying bla $a_{C M Y-2}$ gene from commensal $E$. coli after inoculation of $S$. Heidelberg into chicken ceca in an in vitro study [100]. Smith (1977) found that R plasmid encoded resistance to streptomycin could be transferred from E. coli to S. Lomita in the GIT of sheep [101]. Plasmids and other mobile genetics elements not only can be transmitted between $S$. enterica and commensal bacteria, but also can be transferred among diverse bacteria to disseminate genes into a variety of interacting bacterial communities. It would be very interesting to know another horizontal gene transfer can occur among microorganisms.

\section{HGT among other microorganisms associated with the GIT}

Genes can be disseminated among microorganism in both in vitro and in vivo studies (Table 1 supplement). It was shown that resistance plasmids that contain genes encoding resistance to at least 14 antibiotics were transferred from Serratia liquefaciens isolated from the urine of a patient to E. coli originating from humans [102]. Likewise, the transfer of plasmids carrying multiple antimicrobial resistance genes from $K$. pneumoniae isolated from patient to the E. coli K12 strain occurred at a relatively high rate in the GIT of mice, compared to an in vitro assay [103]. Another study found that IncI1 plasmid carrying an extended-spectrum $\beta$-lactamase gene was able to be transferred from $E$. coli originating from poultry to $E$. coli isolated from a human [104]. Interestingly, plasmids can be conjugatively transferred from Gram-negative to Gram-positive bacteria in some cases [105]. Trieucuot et al (1987) demonstrated that the pAT187 plasmid encoded resistance to kanamycin (aphA-3) could be transferred from E. coli to Enterococcus faecalis, Streptococcus lactis, Streptococcus agalactiae, Bacillus thuringiensis, Listeria monocytogenes and Staphylococcus aureus [105]. On the other hand, the conjugal transfer of the plasmid could also occur from Gram-positive to Gram-negative bacteria. To illustrate, in an in vitro assay it was found that the pBR322pAMII1 chimeric plasmid designated pAT191, encoding resistance to kanamycin (aphA-3), erythromycin (erm), and $\beta$-lactamase, could be transferred from $E$. faecalis to E. coli [106]. Likewise, in germ-free mice, the pBR322pAM $\beta 1$ chimeric vector designated pAt191 plasmid, encoding resistance to kanamycin (aphA-3), was transferred from $E$. faecalis to $E$. coli, indicating that the conjugation could account for the resistance gene flux in bacteria observed in the GIT [107]. Shoemaker and colleagues (2000) confirmed that the Gram-negative Bacteroides species were able to acquire $\operatorname{erm}(B)$ and $\operatorname{tet}(Q)$ genes, encoding resistance to erythromycin and tetracycline from E. faecalis and other Gram-positive bacteria in the GIT of patients [108]. Because the GIT contains densely populated bacteria, there is opportunity for the transfer of genetic elements among bacteria in the GIT. The cumulative set of antimicrobial resistance genes that is harbored by the gastrointestinal microbiota is called the gastrointestinal resistome [109, 110]. Therefore, there is considerable interest to understand as to what extent bacteria can disseminate these genes in the GIT [111]. 
Further evidence for conjugative transfer of resistance genes carried by transposons is illustrated by the members of Firmicutes in the GIT. It was shown that transposon Tn1545, which carries multiple drug resistance determinants such as those for kanamycin (aphA-3), erythromycin (ermAM), and tetracycline (tet $M)$, can be transferred from $E$. faecalis to $L$. monocytogenes in the GIT of gnotobiotic mice at a high rate, compared to in vitro experiments [112]. Moubareck and colleagues (2003) found that transposon Tn1546, which carries vanA and multiple other antibiotic resistance genes, such as $\operatorname{ermB}$, tet( $L)$, ant (6), and tet $M$, can be horizontally transferred from $E$. faecium originating from pigs to E. faecium isolated from humans at a high frequency in the GIT of gnotobiotic mice [113]. This study suggested that different resistance genes can be conjugatively transferred from an E. faecium strain of animal origin to a human-origin bacterium of the same species [113]. Earlier studies found that the transposon $\operatorname{Tn} 1546$ carrying vanA gene was transferred from an E. faecium isolate of chicken origin to an E. faecium isolate of human origin in the intestines of human volunteers [114]. Likewise, another study confirmed that the vanA gene, encoding resistance to vancomycin, can be transferred from $E$. faecium originating from pigs and poultry to $E$. faecalis originating from human in the GIT of gnotobiotic mice [115]. Launay and colleagues (2006) demonstrated that transposon $\operatorname{Tn} 1549$, which carries the vanB2 gene, can be transferred from Clostridium symbiosum to $E$. faecium and E. faecalis in the GIT of gnotobiotic mice at a high rate, compared to in vitro experiments [116]. Also, another study confirmed that the $\operatorname{van} B$ gene, encoding resistance to vancomycin, was transferred among E. faecium in the GIT of patients [117]. It is of central importance to know that conjugative transfer of genes can occur among Bacteroidetes members in the GIT. For instance, it was found conjugative plasmid (pRRI4), encoding to tetracycline resistance gene, was transferred from Prevotella ruminicola to Bacteroides spp [118]. A study indicated that the transfer of Tn5030 carrying clindamycin resistance (ermFU) gene can occur among Bacteroides species [119]. Conjugal transfer of plasmids and conjugative transposons among bacteria appears to be important to the HGT in the GIT. Consequently, the efficiency of HGT among bacteria can be affected by several factors such as SOS response, stress hormones, antibiotic treatment, inflammation, and bacteria-derived factors such as quorum sensing molecules. It is of considerable interest to know the factors that influence HGT.

\section{Factors influencing HGT with S. enterica}

The findings from recent studies indicated that the antibiotic-induced SOS response, which is a global stress response to DNA damage, could promote HGT in bacteria. For example, Bearson and Brunelle (2015) found that the induction of SOS response by antibiotics, such as fluoroquinolones (ciprofloxacin, enrofloxacin and danofloxacin), could facilitate the transfer of plasmid from S. Typhimurium DT120 and DT104 to a recipient kanamycin-susceptible Salmonella [120]. Furthermore, there is also increasing evidence that the impact of antibiotic intake on increased HGT is 3-fold stronger in the resistome of people treated with antimicrobials compared to untreated people (19 and 5\%, respectively) [121]. In addition to antibiotics, norepinephrine (NE), a stress hormone, can contribute significantly to HGT between bacteria. A recent study found that NE enhanced HGT of a conjugative plasmid carrying AMR genes from $S$. Typhimurium to commensal E. coli due to upregulated expression of tra genes in the presence of $\mathrm{NE}$ [122]. A major factor that can influence HGT is inflammation in the GIT. Stecher et al (2012) found that infections with $S$. Typhimurium resulted in an inflammatory response, which prompted HGT of the colicin-plasmid p2 from $S$. Typhimurium to commensal E. coli [21].

Moreover, other studies reported that some gut bacteria-derived factors associated with quorum sensing may promote HGT [123]. Quorum sensing signaling molecules are synthesized by gut microbiota and function to control population density and synchronize bacterial behaviors [124]. One important class of signaling molecules are referred as autoinducers, which are the major signaling molecules involved in quorum sensing. The concentration of autoinducers increase as the bacteria replicate and increase in number allowing for sensing of population densities [125]. The most common class of autoinducers are acyl homoserine lactones (AHLs) [124]. S. enterica and other Gram-negative bacteria encode SdiA, which is a homolog of the well characterized AHL sensor LuxR, but they do not synthesize their own AHLs [126]. However, S. Typhimurium use SdiA as a sensor to detect and respond a variety of AHLs in GIT [127], and potentially influence HGT in the GIT [123]. Interestingly, MuCuddin et al (2006) found that the rumen protozoa are a influencing factor in bacterial gene transfer, enhancing transfer a plasmid carrying the $b l a_{\mathrm{CMY}-2}$ gene from Klebsiella to Salmonella in both in vitro and in vivo studies of bovine, caprine, and ovine species [128].

\section{Promotion or inhibition of S. enterica growth by gut bacteria}

Salmonella infections lead to changes in the gut microbiota composition, certain gut bacteria harvest molecules that serve as nutrients or signals to aid in promotion or limitation of the growth of Salmonella [129, 130]. The exploitation of microbiota-derived molecules is a critical 
issue for both the colonization or decolonization of the host cells by enteric pathogens (Table 3). For example, Bacteroides thetaiotaomicron harvests the fucose, galactose, sialic acid from the gut epithelium [129, 131, 132]. These sugars can be used as a source of carbon by $S$. Typhimurium to promote its expansion in the GIT (Fig. 4) [129]. Also, hydrogen, which is a central intermediate of microbiota metabolism, can be used as an energy source to enhance the growth of $S$. Typhimurium during the early stages of infection [133]. This growth was enhanced by $S$. Typhimurium hyb hydrogenase, which facilitates consumption of hydrogen [133]. Moreover, SCFAs that are produced by members of the GIT microbiota play an important role in colonization of pathogenic bacteria in the GIT. To illustrate, it was shown that the high concentration of acetate in the distal ileum enhanced the expression of the invasion genes of SPI-1 encoded T3SS through sensor kinase (BarA) and response regulator (SirA) pathways (Fig. 4) [134]. In brief, acetate can be converted to acetylphosphate by acetate kinase (AckA), which could phosphorylate BarA and SirA. SirA is essential for the expression of SPI- 1 invasion genes [134].

Conversely, propionate and butyrate suppressed the expression of the invasion genes of SPI-1 encoded T3SS [134]. Jacobson and colleagues (2018) demonstrated that the production of propionate by Bacteroides spp. limited the growth of $S$. Typhimurium by disrupting intracellular $\mathrm{pH}$ homeostasis in an in vivo study [130]. Another study found that pre-incubation of $S$. Enteritidis with propionate and butyrate could decrease the invasion of the intestinal epithelial cells in an in vitro avian model [135]. Although the intestinal microbiota is complex and the role of most of the bacteria in providing benefit to the host is not clear, bacterial species of the genera Lactobacillus have been shown to supply protection against enteric infections. Peng and colleagues (2015) suggested that Lactobacillus casei could inhibit the growth of pathogens by 99\% [136]. More specifically, they found that linoleic acids that were produced by $L$. casei, limited the growth of $S$. Typhimurium [137]. Furthermore, Makras et al (2006) found that the inhibitory activity of four of six examined Lactobacillus strains against $S$. Typhimurium was solely due to lactic acid production, while that of the remaining two was due to lactic acid plus another unknown substance [138]. In addition, indole is produced by commensal $E$. coli and could be important in the intestinal epithelial cell response to pathogens [139]. Evidence provided by the authors observed that indole downregulated the expression of the SPI-1 T3SS genes of S. Typhimurium [140]. Remarkably, there are other pathogens that can also exploit nutrients or molecules for the successful infection of host cells, and it would be very interesting to know other pathogenic bacteria compete and use the molecules harvested by the gut bacteria (Table 2 supplement).

It has been found that fucose harvested by B. thetaiotaomicron repressed the expression of virulence genes in enterohaemorrhagic E. coli (EHEC) serovar O157:H7 encoded T3SS through the FusK and FusR signaling cascade [132]. On the other hand, B. thetaiotaomicron modified the metabolites by increasing succinate, which can lead to enhance EHEC virulence gene expression through the transcription factor, Cra, which is functionally sensitive to succinate [141]. Takao et al (2014) found that butyrate produced by the gut microbiota enhanced the expression of leuO gene that activated the locus for enterocyte effacement (LEE) genes and flagella biosynthesis genes in EHEC-encoded T3SS [142]. Likewise, butyrate enhanced the expression of the Shiga toxin (Stx) receptor globotriaosylceramide (Gb3) on the colonic epithelium and increased susceptibility to EHEC infection

Table 3 Summary of certain members of the gut microbiota promotion or inhibition of S. enterica growth in the GIT

\begin{tabular}{|c|c|c|c|}
\hline Gut microbiota & $\begin{array}{l}\text { Type of molecules produced by gut } \\
\text { microbiota }\end{array}$ & The result of study & Reference \\
\hline $\begin{array}{l}\text { Bacteroides } \\
\text { thetaiotaomicron }\end{array}$ & Fucose, galactose, sialic acid & Enhance the growth of S. Typhimurium & $\begin{array}{l}{[129,131} \\
132]\end{array}$ \\
\hline $\begin{array}{l}\text { Microbiota-derived } \\
\mathrm{H} 2\end{array}$ & Hydrogen $(\mathrm{H} 2)$ & $\begin{array}{l}\text { Enhance the growth of S. Typhimurium during the early stage } \\
\text { infection }\end{array}$ & [133] \\
\hline $\begin{array}{l}\text { Microbiota- derived } \\
\text { SCFAs }\end{array}$ & Acetate & $\begin{array}{l}\text { Enhance the expression of the invasion genes of SPI-1 encoded T3SS } \\
\text { of S. Typhimurium }\end{array}$ & [134] \\
\hline $\begin{array}{l}\text { Microbiota- derived } \\
\text { SCFAs }\end{array}$ & Propionate and butyrate & $\begin{array}{l}\text { Suppress the expression of the invasion genes of SPI-1 encoded T3SS } \\
\text { of S. Typhimurium }\end{array}$ & [134] \\
\hline $\begin{array}{l}\text { Microbiota- derived } \\
\text { SCFAs }\end{array}$ & Propionate & Limit S. Typhimurium growth & [130] \\
\hline $\begin{array}{l}\text { Microbiota- derived } \\
\text { SCFAs }\end{array}$ & Propionate and butyrate & $\begin{array}{l}\text { Decrease the invasion of the intestinal epithelial cells in an in vitro } \\
\text { avian model of } S \text {. Enteritidis }\end{array}$ & [135] \\
\hline Lactobacillus casei & Linoleic acids & Limit S. Typhimurium growth & [137] \\
\hline Commensal E. coli & Indole & Downregulated genes of SPI-1 encoded T3SS of S. Typhimurium & {$[139,140]$} \\
\hline
\end{tabular}




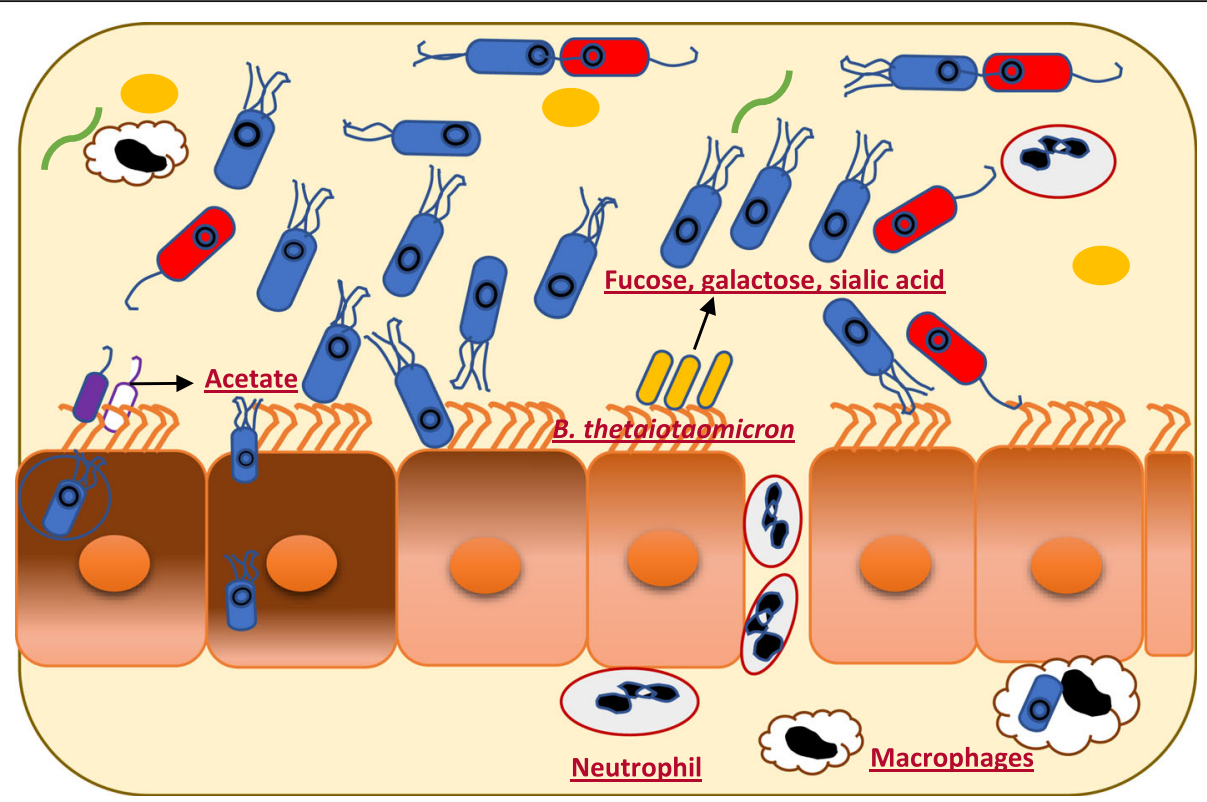

Fig. 4 Bacteroides thetaiotaomicron, harvests the fucose, galactose, sialic acid from the gut epithelium and used as a source of carbon by Salmonella to promote its expansion in the GIT. Acetate produced by commensal microbiota enhanced expression of the invasion genes of SPI-1 encoded T3SS of Salmonella

[143]. Acyl-homoserine lactones (AHLs) produced by some members of Bacteroidetes can be used by EHEC through sensor protein SdiA to successfully colonize in the intestinal epithelium of cattle [144]. However, molecules that are modified by the gut microbiota can be detected by pathogens and control their virulence genes. For instance, the metabolic conversion of bile acids into deoxycholic acid by some members of the gut bacteria, such as Bifidobacterium bifidum, can decrease the expression of virulence genes in Vibrio cholerae encoded type VI secretion system (T6SS), which is used to kill other bacteria [145].

\section{Conclusion}

The human gastrointestinal microbiota is a complex of microorganisms that has received much attention because of its impact on human health and disease. Recent insights into the interaction between Salmonella, the host and its microbiota, found that Salmonella has evolved molecular machineries that allows them to adapt to the inflamed intestine and compete with the gut microbiota. Thereby genes can be transferred horizontally between pathogens and microbial communities that lead to changes in the GIT bacterial structure and their behavior. Together, this interplay could result in risks to human health, for example, the human colon can serve as an environment that acts as a reservoir for antimicrobial resistance and mobile genetics elements. The transfer of MGEs harboring multiple resistance genes and virulence factors from pathogens to human intestinal bacteria has centered around the questions such as: what happens to the transferred MGEs once entering the gut microbiota, and which mechanisms that certain gut bacteria use for HGT can contribute to increasing the virulence factors associated with salmonellosis? Although several recent studies started to focus on understanding the shifts in the taxonomic composition of the developing microbiota from infancy to adulthood; the review of the literature showed that much remains to be learned due to the limited knowledge of the effect of Salmonella infection on the microbial composition, as well as on the MGEs in the gut microbiota, including the transmission and persistence of antimicrobial resistance genes.

$S$. Typhimurium has been widely studied as a pathogen and is known to create its own niche in the intestine by causing inflammation, alteration the composition of gut microbiota, and using nutrients produced by gut microbiota. We reviewed many of the latest insights describing the interactions between the microbiota, the host, and pathogenic bacteria in animal models, and it is evident that further studies are needed to better understand the interaction of the gastrointestinal microbiota of different hosts and Salmonella serotypes most associated with infections. S. Typhimurium has developed mechanisms to rapidly transfer the genes into the gut bacteria at a higher rate in vivo than found in in vitro studies. Although the gut microbiota likely influences $S$. Typhimurium infection kinetics, the effects of molecules produced by gut bacteria on the expression of virulence genes in $S$. Typhimurium is not yet well defined. SCFA produced by 
bacteria may have utility as therapeutics targets or the for successful prevention against Salmonella infection. Likewise, approaches to impact quorum sensing pathways in Salmonella and other enteric pathogens could potentially minimize the role of HGT on AMR and virulence factor transmission conserving potential therapeutic options for control of infections.

\section{Supplementary information}

Supplementary information accompanies this paper at https://doi.org/10. 1186/s12866-020-02008-x.

\section{Additional file 1.}

\section{Abbreviations}

GIT: Gastrointestinal tract; SCFAs: Short-chain fatty acids; MGEs: Mobile genetic elements; SPI-1: Salmonella pathogenicity island-1; SPI-2: Salmonella pathogenicity island - 2; T3SS: Type III secretion system; Sips: Salmonella invasive proteins; Sops: Salmonella outer proteins; SCV: Salmonella containing vacuole; NK: Natural Killer; TLRs: Toll-like receptors; PAMPs: Pathogenassociated molecular patterns; NO: Nitric oxide; ROS: Reactive oxygen species; HGT: Horizontal gene transfer; EcN: E. coli Nissle; STEC: Shiga toxinproducing E. coli; LGT: Lateral gene transfer; AMR: Antimicrobial resistance; MLS: Macrolides, lincosamide and streptogramin; NE: Norepinephrine; BarA: Sensor kinase; SirA: Response regulator; AckA: Acetate kinase; EHEC: Enterohaemorrhagic E. coli; AHLs: Acyl-homoserine lactones; T6SS: Type VI secretion system

\section{Acknowledgements}

The authors would like to recognize Drs. Ashraf Khan, Saeed Khan and Carl Cerniglia for their critical review of the manuscript. Dr. Nesreen Aljahdali was supported in part by an appointment to the Research Participation Program at the National Center for Toxicological Research administered by the Oak Ridge Institute for Science and Education (ORISE) through an interagency agreement between the U.S. Department of Energy and the U.S. Food and Drug Administration. The opinions expressed in this manuscript are solely the responsibility of the authors and do not necessarily represent the official views and policy of the Food and Drug Administration or Department of Health and Human Services.

\section{Authors' contributions}

NA wrote the first draft of the manuscript. NA and SF coordinated the writing of the manuscript. YS and JH contributed to manuscript writing. All contributed to the editing and refinement of the final version of the manuscript. The author(s) read and approved the final manuscript.

\section{Funding}

Not applicable.

\section{Availability of data and materials}

Not applicable.

\section{Ethics approval and consent to participate}

Not applicable.

\section{Consent for publication}

Not applicable.

\section{Competing interests}

The authors declare that they do not have competing interests.

\section{Author details}

'Division of Microbiology, National Center for Toxicological Research, U.S. Food and Drug Administration, 3900 NCTR Rd, Jefferson, AR 72079, USA. ${ }^{2}$ Biological Science Department, College of Science, King Abdul-Aziz University, Jeddah, Saudi Arabia. ${ }^{3}$ Department of Agriculture, University of
Arkansas, Pine Bluff, AR, USA. ${ }^{4}$ Department of Parasitology and Animal Diseases, Veterinary Research Division, National Research Centre, Giza, Egypt.

Received: 6 July 2020 Accepted: 12 October 2020

Published online: 17 November 2020

\section{References}

1. Tsolis RM, Young GM, Solnick JV, Bäumler AJ. From bench to bedside: stealth of enteroinvasive pathogens. Nat Rev Microbiol. 2008;6(12):883-92.

2. Kolling G, Wu M, Guerrant RL. Enteric pathogens through life stages. Front Cell Infect Microbiol. 2012;2:8.

3. National Salmonella Surveillance [https://www.cdc.gov/nationalsurveillance/ salmonella-surveillance.html]. Accessed 15 Oct 2020.

4. Nastasi A, Mammina C, Villafrate MR, Massenti MF, Scarlata G, Diquattro M. Multiple typing of strains of Salmonella enterica subsp. Bongori ser. 48:Z35:isolated in southern Italy. Ann Inst Pasteur Microbiol. 1988;139(5):605-12.

5. Pui CF, Wong WC, Chai LC, Tunung R, Jeyaletchumi P, Noor Hidayah MS, Ubong A, Farinazleen MG, Cheah YK, Son R. Salmonella: a foodborne pathogen. Int Food Res J. 2011;18(2):4-473.

6. Su LH, Chiu CH. Salmonella: Clinical importance and evolution of nomenclature. Chang Gung Med J. 2007;30(3):210-9.

7. Foley SL, Johnson TJ, Ricke SC, Nayak R, Danzeisen J. Salmonella pathogenicity and host adaptation in chicken-associated serovars. Microbiol Mol Biol Rev. 2013;77(4):582-607.

8. Voogt N, Wannet WJ, Nagelkerke NJ, Henken AM. Differences between national reference laboratories of the European community in their ability to serotype Salmonella species. Eur J Clin Microbiol Infect Dis. 2002;21(3): 204-8.

9. Scallan E, Hoekstra RM, Angulo FJ, Tauxe RV, Widdowson MA, Roy SL, Jones $J$, Griffin PM. Foodborne illness acquired in the United States-major pathogens. Emerg Infect Dis. 2011;17(1):7-15.

10. Kennedy M, Villar R, Vugia DJ, Rabatsky-Ehr T, Farley MM, Pass M, Smith K, Smith P, Cieslak PR, Imhoff B, et al. Hospitalizations and deaths due to Salmonella infections, FoodNet, 1996-1999. Clin Infect Dis. 2004;38:S142-8.

11. Han J, Lynne AM, David DE, Tang HL, Xu JS, Nayak R, Kaldhone P, Logue CM, Foley SL. DNA sequence analysis of plasmids from multidrug resistant Salmonella enterica serotype Heidelberg isolates. PLoS One. 2012;7(12):8.

12. Hiyoshi H, Tiffany CR, Bronner DN, Bäumler AJ. Typhoidal Salmonella serovars: ecological opportunity and the evolution of a new pathovar. FEMS Microbiol Rev. 2018;42(4):527-41

13. Johnson R, Mylona E, Frankel G. Typhoidal Salmonella: distinctive virulence factors and pathogenesis. Cell Microbiol. 2018;20(9):e12939.

14. Information for Healthcare Professionals and Laboratories [https://www.cdc. gov/salmonella/general/technical.html]. Accessed 15 Oct 2020.

15. Haselbeck AH, Panzner U, Im J, Baker S, Meyer CG, Marks F. Current perspectives on invasive nontyphoidal Salmonella disease. Curr Opin Infect Dis. 2017;30(5):498-503.

16. Jones TF, Ingram LA, Cieslak PR, Vugia DJ, Tobin-D'Angelo M, Hurd S, Medus C, Cronquist A, Angulo FJ. Salmonellosis outcomes differ substantially by serotype. J Infect Dis. 2008;198(1):109-14.

17. Brenner FW, Villar RG, Angulo FJ, Tauxe R, Swaminathan B. Salmonella nomenclature. J Clin Microbiol. 2000;38(7):2465-7.

18. Jackson BR, Griffin PM, Cole D, Walsh KA, Chai SJ. Outbreak-associated Salmonella enterica serotypes and food commodities, United States, 19982008. Emerg Infect Dis. 2013;19(8):1239-44.

19. Parry CM, Threlfall EJ. Antimicrobial resistance in typhoidal and nontyphoidal Salmonellae. Curr Opin Infect Dis. 2008;21(5):531-8.

20. Walter J, Ley R. The human gut microbiome: Ecology and recent evolutionary changes. Annu Rev Microbiol. 2011:65:411-29 Palo Alto: Annual Reviews; Edited by Gottesman S, Harwood CS, vol. 65.

21. Stecher B, Denzler R, Maier L, Bernet F, Sanders MJ, Pickard DJ, Barthel M, Westendorf AM, Krogfelt KA, Walker AW, et al. Gut inflammation can boost horizontal gene transfer between pathogenic and commensal Enterobacteriaceae. Proc Natl Acad Sci U S A. 2012;109(4):1269-74.

22. Martin R, Miquel S, Ulmer J, Langella P, Bermudez-Humaran LG. Gut ecosystem: how microbes help us. Benefic Microbes. 2014;5(3):219-33.

23. Caporaso JG, Lauber CL, Costello EK, Berg-Lyons D, Gonzalez A, Stombaugh J, Knights D, Gajer P, Ravel J, Fierer N, et al. Moving pictures of the human microbiome. Genome Biol. 2011;12(5):8.

24. Thiennimitr P, Winter SE, Baumler AJ Salmonella, the host and its microbiota. Curr Opin Microbiol. 2012;15(1):108-14. 
25. Ley RE, Peterson DA, Gordon Jl. Ecological and evolutionary forces shaping microbial diversity in the human intestine. Cell. 2006;124(4):837-48.

26. Noverr MC, Huffnagel GB. Does the microbiota regulate immune responses outside the gut? Trends Microbiol. 2004;12(12):562-8.

27. Ohoka M, Ito T, Kitsunezaki M, Nomoto K, Bando Y, Ishii M. Changes in neonatal microbiota distribution influenced by the environment of the neonatal intensive care unit in the first month of life. J Neonatal Biol. 2016; 5(2):1-7.

28. Palmer C, Bik EM, DiGiulio DB, Relman DA, Brown PO. Development of the human infant intestinal microbiota. PLoS Biol. 2007;5(7):1556-73.

29. Mariat D, Firmesse O, Levenez F, Guimaraes VD, Sokol H, Dore J, Corthier G, Furet JP. The Firmicutes/Bacteroidetes ratio of the human microbiota changes with age. BMC Microbiol. 2009;9:6.

30. Gill SR, Pop M, DeBoy RT, Eckburg PB, Turnbaugh PJ, Samuel BS, Gordon I, Relman DA, Fraser-Liggett CM, Nelson KE. Metagenomic analysis of the human distal gut microbiome. Science. 2006;312(5778):1355-9.

31. Gibson GR, Roberfroid MB. Dietary modulation of the human colonic microbiota - introducing the concept of prebiotics. J Nutrition. 1995;125(6): 1401-12.

32. Duncan SH, Hold GL, Barcenilla A, Stewart CS, Flint HJ. Roseburia intestinalis sp nov., a novel saccharolytic, butyrate-producing bacterium from human faeces. Int J Syst Evol Microbiol. 2002;52:1615-20.

33. Wong JMW, de Souza R, Kendall CWC, Emam A, DJA J. Colonic health: Fermentation and short chain fatty acids. J Clin Gastroenterol. 2006;40(3): 235-43.

34. Evenepoel P, Meijers BKI, Bammens BRM, Verbeke K. Uremic toxins originating from colonic microbial metabolism. Kidney Int. 2009;76:S12-9.

35. Macfarlane GT, Cummings JH, Allison C. Protein-degradation by human intestinal bacteria. J Gen Microbiol. 1986;132:1647-56.

36. Hoffman S, Maculloch B, Batz M. Economic Burden of Major Foodborne Illnesses Acquired in the United States. EIB-140, U.S. Deptartment of Agriculture, Economic Research Service. 2015. https://www.ers.usda.gov/ publications/pub-details/?pubid=43987. Accessed 15 Oct 2020.

37. Cost Estimates of Foodborne IIInesses, Cost of Foodborne IIIness Estimates for Salmonella (non-typhoidal) [https://www.ers.usda.gov/data-products/ costestimates-of-foodborne-illnesses.aspx\#48498]. Accessed 15 Oct 2020.

38. National Enteric Disease Surveillance Salmonella Annual Report [ https:// www.cdc.gov/salmonella/index.html]. Accessed 15 Oct 2020.

39. Darwin $\mathrm{KH}$, Miller VL. Molecular basis of the interaction of Salmonella with the intestinal mucosa. Clin Microbiol Rev. 1999;12(3):405.

40. Foley SL, Lynne AM. Food animal-associated Salmonella challenges: pathogenicity and antimicrobial resistance. J Anim Sci. 2008;86(14 Suppl): E173-87.

41. Hanning IB, Nutt JD, Ricke SC. Salmonellosis outbreaks in the United States due to fresh produce: sources and potential intervention measures. Foodborne Pathog Dis. 2009;6(6):635-48.

42. Howard ZR, O'Bryan CA, Crandall PG, Ricke SC. Salmonella Enteritidis in shell eggs: current issues and prospects for control. Food Res Int. 2012;45(2):755-64.

43. Ricke SC. Insights and challenges of Salmonella infection of laying hens. Curr Opin Curr Opin Food Sci. 2017;18:43-9.

44. Trevejo R, Starr M. Re: "epidemiology of salmonellosis in California, 19901999: morbidity, mortality, and hospitalization costs" - reply. Am J Epidemiol. 2004;159(1):104-5.

45. Bula-Rudas FJ, Rathore MH, Maraqa NF. Salmonella infections in childhood. Adv Pediatr Infect Dis. 2015;62(1):29-58.

46. Jakociune D, Bisgaard M, Pedersen K, Olsen JE. Demonstration of persistent contamination of a cooked egg product production facility with Salmonella enterica serovar Tennessee and characterization of the persistent strain. J Appl Microbiol. 2014;117(2):547-53.

47. Hancock D, Besser T, Gay J, Rice D, Davis M, Gay C. The global epidemiology of multiresistant Salmonella enterica serovar Typhimurium DT104. Washington: Amer Soc Microbiology; 2000.

48. Rabsch W, Tschape H, Baumler AJ. Non-typhoidal salmonellosis: emerging problems. Microb Infect. 2001;3(3):237-47.

49. Foster JW. Salmonella acid shock proteins are required for the adaptive acid tolerance response. J Bacteriol. 1991;173(21):6896-902.

50. Foley SL, Nayak R, Hanning IB, Johnson TJ, Han J, Ricke SC. Population dynamics of Salmonella enterica serotypes in commercial egg and poultry production. Appl Environ Microbiol. 2011;77(13):4273-9.

51. Lostroh CP, Lee CA. The Salmonella pathogenicity island-1 type III secretion system. Microb Infect. 2001;3(14-15):1281-91.
52. Lopez CA, Winter SE, Rivera-Chavez F, Xavier MN, Poon V, Nuccio SP, Tsolis RM, Baumler AJ. Phage-Mediated Acquisition of a Type III Secreted Effector Protein Boosts Growth of Salmonella by Nitrate Respiration. mBio. 2012;3(3):10.

53. Haraga A, Ohlson MB, Miller SI. Salmonellae interplay with host cells. Nat Rev Microbiol. 2008;6(1):53-66.

54. Knodler LA, Steele-Mortimer O. Taking possession: biogenesis of the Salmonella-containing vacuole. Traffic. 2003;4(9):587-99.

55. Khajanchi BK, Hasan NA, Choi SY, Han J, Zhao SH, Colwell RR, Cerniglia CE, Foley SL. Comparative genomic analysis and characterization of incompatibility group FIB plasmid encoded virulence factors of Salmonella enterica isolated from food sources. BMC Genomics. 2017;18:14.

56. Kaldhone PR, Carlton A, Aljahdali N, Khajanchi BK, Sanad YM, Han J, Deck J, Ricke SC, Foley SL. Evaluation of incompatibility group I1 (Incl1) plasmidcontaining Salmonella enterica and assessment of the plasmids in bacteriocin production and biofilm development. Front Vet Sci. 2019;6:298.

57. Gokulan K, Khare S, Rooney AW, Han J, Lynne AM, Foley SL. Impact of plasmids, including those encoding VirB4/D4 type iv secretion systems, on Salmonella enterica serovar Heidelberg virulence in macrophages and epithelial cells. PLoS One. 2013;8(10):13.

58. Pham TA, Clare S, Goulding D, Arasteh JM, Stares MD, Browne HP, Keane JA, Page AJ, Kumasaka N, Kane L, et al. Epithelial IL-22RA1-mediated fucosylation promotes intestinal colonization resistance to an opportunistic pathogen. Cell Host Microbe. 2014;16(4):504-16.

59. Santos RL, Zhang S, Tsolis RM, Baumler AJ, Adams LG. Morphologic and molecular characterization of Salmonella Typhimurium infection in neonatal calves. Vet Pathol. 2002;39(2):200-15.

60. Loetscher $Y$, Wieser A, Lengefeld J, Kaiser P, Schubert S, Heikenwalder M, Hardt WD, Stecher B. Salmonella transiently reside in luminal neutrophils in the inflamed gut. PLoS One. 2012;7(4):11.

61. Broz P, Ohlson MB, Monack DM. Innate immune response to Salmonella Typhimurium, a model enteric pathogen. Gut Microbes. 2012;3(2):62-70.

62. Schairer DO, Chouake JS, Nosanchuk JD, Friedman AJ. The potential of nitric oxide releasing therapies as antimicrobial agents. Virulence. 2012;3(3):271-9.

63. Muller AA, Dolowschiak T, Sellin ME, Felmy B, Verbree C, Gadient S, Westermann AJ, Vogel J, LeibundGut-Landmann S, Hardt WD. An NK cell perforin response elicited via il-18 controls mucosal inflammation kinetics during Salmonella gut infection. PLoS Pathog. 2016;12(6):30.

64. Zheng Y, Valdez PA, Danilenko DM, Hu Y, Sa SM, Gong Q, Abbas AR, Modrusan Z, Ghilardi N, de Sauvage FJ, et al. Interleukin-22 mediates early host defense against attaching and effacing bacterial pathogens. Nat Med. 2008;14(3):282-9.

65. Sassone-Corsi M, Raffatellu M. No vacancy: how beneficial microbes cooperate with immunity to provide colonization resistance to pathogens. J Immunol. 2015;194(9):4081-7.

66. Santos RL, Raffatellu M, Bevins CL, Adams LG, Tukel C, Tsolis RM, Baumler AJ. Life in the inflamed intestine, Salmonella style. Trends Microbiol. 2009;17(11): 498-506.

67. Winter SE, Thiennimitr P, Winter MG, Butler BP, Huseby DL, Crawford RW, Russell JM, Bevins CL, Adams LG, Tsolis RM, et al. Gut inflammation provides a respiratory electron acceptor for Salmonella. Nature. 2010;467(7314):426-9.

68. Thiennimitr P, Winter SE, Winter MG, Xavier MN, Tolstikov V, Huseby DL, Sterzenbach T, Tsolis RM, Roth JR, Baumler AJ. Intestinal inflammation allows Salmonella to use ethanolamine to compete with the microbiota. Proc Natl Acad Sci U S A. 2011;108(42):17480-5.

69. Hausmann A, Hardt WD. The interplay between Salmonella enterica serovar Typhimurium and the intestinal mucosa during oral infection. Microbiol Spectr. 2019;7(2):16.

70. Flo TH, Smith KD, Sato S, Rodriguez DJ, Holmes MA, Strong RK, Akira S, Aderem A. Lipocalin 2 mediates an innate immune response to bacterial infection by sequestrating iron. Nature. 2004;432(7019):917-21.

71. Raffatellu M, George MD, Akiyama Y, Hornsby MJ, Nuccio SP, Paixao TA, Butler BP, Chu HT, Santos RL, Berger T, et al. Lipocalin-2 resistance confers an advantage to Salmonella enterica serotype Typhimurium for growth and survival in the inflamed intestine. Cell Host Microbe. 2009; 5(5):476-86.

72. Ducarmon QR, Zwittink RD, Hornung BVH, van Schaik W, Young VB, Kuijper EJ. Gut microbiota and colonization resistance against bacterial enteric infection. Microbiol Mol Biol Rev. 2019;83(3):29.

73. Sassone-Corsi M, Nuccio SP, Liu H, Hernandez D, Vu CT, Takahashi AA, Edwards RA, Raffatellu M. Microcins mediate competition among Enterobacteriaceae in the inflamed gut. Nature. 2016;540(7632):280. 
74. Borewicz KA, Kim HB, Singer RS, Gebhart CJ, Sreevatsan S, Johnson T, Isaacson RE. Changes in the porcine intestinal microbiome in response to infection with Salmonella enterica and Lawsonia intracellularis. PLoS One. 2015;10(10):16.

75. Arguello H, Estelle J, Zaldivar-Lopez S, Jimenez-Marin A, Carvajal A, Lopez-Bascon MA, Crispie F, O'Sullivan O, Cotter PD, Priego-Capote F, et al. Early Salmonella Typhimurium infection in pigs disrupts microbiome composition and functionality principally at the ileum mucosa. Sci Rep. 2018;8:12

76. Drumo R, Pesciaroli M, Ruggeri J, Tarantino M, Chirullo B, Pistoia C, Petrucci P, Martinelli N, Moscati L, Manuali E, et al. Salmonella enterica Serovar Typhimurium exploits inflammation to modify swine intestinal microbiota. Front Cell Infect Microbiol. 2016:5:13.

77. Bratburd JR, Keller C, Vivas E, Gemperline E, Li LJ, Rey FE, Currie CR. Gut Microbial and Metabolic Responses to Salmonella enterica Serovar Typhimurium and Candida albicans. mBio. 2018;9(6):14.

78. Barman M, Unold D, Shifley K, Amir E, Hung K, Bos N, Salzman N. Enteric salmonellosis disrupts the microbial ecology of the murine gastrointestinal tract. Infect Immun. 2008;76(3):907-15.

79. Liu LY, Lin LL, Zheng LN, Tang H, Fan XZ, Xue NG, Li M, Liu M, Li XY. Cecal microbiome profile altered by Salmonella enterica, serovar Enteritidis inoculation in chicken. Gut Pathog. 2018;10:14.

80. Mon KK, Saelao P, Halstead MM, Chanthavixay G, Chang HC, Garas L, Maga EA, Zhou H. Salmonella enterica serovar Enteritidis infection alters the indigenous microbiota diversity in young layer chicks. Front Vet Sci. 2015;2:61.

81. Videnska P, Sisak F, Havlickova H, Faldynova M, Rychlik I. Influence of Salmonella enterica serovar Enteritidis infection on the composition of chicken cecal microbiota. BMC Vet Res. 2013;9:8

82. Juricova H, Videnska P, Lukac M, Faldynova M, Babak V, Havlickova H, Sisak F, Rychlik I. Influence of Salmonella enterica Serovar Enteritidis infection on the development of the cecum microbiota in newly hatched chicks. Appl Environ Microbiol. 2013;79(2):745-7.

83. Singh $P$, Teal TK, Marsh TL, Tiedje JM, Mosci R, Jernigan K, Zell A, Newton DW, Salimnia $H$, Lephart $P$, et al. Intestinal microbial communities associated with acute enteric infections and disease recovery. Microbiome. 2015;3:12.

84. Soucy SM, Huang J, Gogarten JP. Horizontal gene transfer: building the web of life. Nat Rev Genet. 2015;16(8):472-82.

85. Jeong $\mathrm{H}$, Arif B, Caetano-Anolles G, Kim KM, Nasir A. Horizontal gene transfer in human-associated microorganisms inferred by phylogenetic reconstruction and reconciliation. Sci Rep. 2019;9:18.

86. Lerner A, Matthias T, Aminov R. Potential effects of horizontal gene exchange in the human gut. Front Immunol. 2017;8:14

87. Stecher B, Maier L, Hardt WD. 'Blooming' in the gut: how dysbiosis might contribute to pathogen evolution. Nat Rev Microbiol. 2013;11(4): 277-84.

88. Hehemann JH, Correc G, Barbeyron T, Helbert W, Czjzek M, Michel G. Transfer of carbohydrate-active enzymes from marine bacteria to Japanese gut microbiota. Nature. 2010;464(7290):908-U123.

89. Salyers AA, Gupta A, Wang YP. Human intestinal bacteria as reservoirs for antibiotic resistance genes. Trends Microbiol. 2004;12(9):412-6.

90. Begley M, Hill C, Gahan CG. Bile salt hydrolase activity in probiotics. Appl Environ Microbiol. 2006;72(3):1729-38.

91. Scott KP. The role of conjugative transposons in spreading antibiotic resistance between bacteria that inhabit the gastrointestinal tract. Cell Mole Life Sci. 2002;59(12):2071-82.

92. Stecher B, Robbiani R, Walker AW, Westendorf AM, Barthel M, Kremer M, Chaffron S, Macpherson AJ, Buer J, Parkhill J, et al. Salmonella enterica serovar typhimurium exploits inflammation to compete with the intestinal microbiota. PLoS Biol. 2007:5(10):2177-89.

93. Faure S, Perrin-Guyomard A, Delmas JM, Laurentie M. Impact of therapeutic treatment with beta-lactam on transfer of the bla (CTX-M-9) resistance gene from Salmonella enterica Serovar Virchow to Escherichia coli in Gnotobiotic rats. Appl Environ Microbiol. 2009;75(17):5523-8

94. Faure S, Perrin-Guyomard A, Delmas JM, Chatre P, Laurentie M. Transfer of plasmid-mediated CTX-M-9 from Salmonella enterica serotype Virchow to Enterobacteriaceae in human Flora-associated rats treated with Cefixime. Antimicrob Agents Chemother. 2010;54(1):164-9.

95. Card RM, Cawthraw SA, Nunez-Garcia J, Ellis RJ, Kay G, Pallen MJ, Woodward MJ, Anjum MF. An In Vitro Chicken Gut Model Demonstrates Transfer of a Multidrug Resistance Plasmid from Salmonella to Commensal Escherichia coli. mBio. 2017:8(4):15
96. Aviv G, Rahav G, Gal-Mor O. Horizontal transfer of the Salmonella enterica serovar Infantis resistance and virulence plasmid pESI to the Gut Microbiota of Warm-Blooded Hosts. mBio. 2016;7:5

97. Su LH, Chiu CH, Chu C, Wang MH, Chia JH, Wu TL. In vivo acquisition of ceftriaxone resistance in Salmonella enterica serotype anatum. Antimicrob Agents Chemother. 2003;47(2):563-7.

98. Archambaud M, Gerbaud G, Labau E, Marty N, Courvalin P. Possible in vivo transfer of beta-lactamase tem-3 from Klebsiella pneumoniae to SalmonellaKedougou. J Antimicrob Chemother. 1991;27(4):427-36.

99. Poppe C, Martin LC, Gyles CL, Reid-Smith R, Boerlin P, McEwen SA, Prescott JF, Forward KR. Acquisition of resistance to extended-spectrum Cephalosporins by Salmonella enterica subsp enterica serovar Newport and Escherichia coli in the Turkey poult intestinal tract. Appl Environ Microbiol. 2005;71(3):1184-92.

100. Oladeinde A, Cook K, Lakin SM, Woyda R, Abdo Z, Looft T, Herrington K, Zock G, Lawrence JP, Thomas JC, et al. Horizontal gene transfer and acquired antibiotic resistance in Salmonella enterica Serovar Heidelberg following in vitro incubation in broiler ceca. Appl Environ Microbiol. 2019; 85(22): 16

101. Smith MG. Transfer of $R$ factors from Escherichia coli to Salmonella in the rumen of sheep. J Med Microbiol. 1977;10(1):29-35.

102. Duval-Iflah Y, Raibaud P, Tancrede C, Rousseau M. R-plasmic transfer from Serratia liquefaciens to Escherichia coli in vitro and in vivo in the digestive tract of gnotobiotic mice associated with human fecal flora. Infect Immun. 1980;28(3):981-90

103. Schjorring S, Struve C, Krogfelt KA. Transfer of antimicrobial resistance plasmids from Klebsiella pneumoniae to Escherichia coli in the mouse intestine. J Antimicrob Chemother. 2008;62(5):1086-93.

104. Smet A, Rasschaert G, Martel A, Persoons D, Dewulf J, Butaye P, Catry B, Haesebrouck F, Herman L, Heyndrickx M. In situ ESBL conjugation from avian to human Escherichia coli during cefotaxime administration. J Appl Microbiol. 2011;110(2):541-9.

105. Trieucuot $P$, Carlier C, Martin P, Courvalin P. Plasmid transfer by conjugation from Escherichia coli to gram-positive bacteria. FEMS Microbiol Lett. 1987: 48(1-2):289-94

106. Trieucuot $P$, Carlier C, Courvalin P. Conjugative plasmid transfer from Enterococcus faecalis to Escherichia coli. J Bacteriol. 1988;170(9):4388-91.

107. Doucetpopulaire F, Trieucuot P, Andremont A, Courvalin P. Conjugal transfer of plasmid dna from Enterococcus faecalis to Escherichia coli in digestive tracts of gnotobiotic mice. Antimicrob Agents Chemother. 1992;36(2):502-4

108. Shoemaker NB, Vlamakis H, Hayes K, Salyers AA. Evidence for extensive resistance gene transfer among Bacteroides spp. and among Bacteroides and other genera in the human colon. Appl Environ Microbiol. 2001;67(2):561-8.

109. Bag S, Shankar Ghosh T, Banerjee S, Mehta O, Verma J, Dayal M, Desigamani A, Kumar P, Saha B, Kedia S, et al. Molecular insights into antimicrobial resistance traits of commensal human gut microbiota. Microb Ecol. 2019; 77(2):546-57.

110. van Schaik W. The human gut resistome. Philos Trans R Soc B-Biol Sci. 2015: 370(1670):9

111. Salyers AA. Gene transfer in the mammalian intestinal tract. Curr Opin Biotechnol. 1993:4(3):294-8.

112. Doucetpopulaire F, Trieucuot P, Dosbaa I, Andremont A, Courvalin P. Inducible transfer of conjugative transposon Tn1545 from Enterococcus faecalis to Listeria monocytogenes in the digestive tracts of gnotobiotic mice. Antimicrob Agents Chemother. 1991;35(1):185-7.

113. Moubareck C, Bourgeois N, Courvalin P, Doucet-Populaire F. Multiple antibiotic resistance gene transfer from animal to human enterococci in the digestive tract of gnotobiotic mice. Antimicrob Agents Chemother. 2003; 47(9):2993-6.

114. Lester CH, Frimodt-Moller N, Sorensen TL, Monnet DL, Hammerum AA. In vivo transfer of the vanA resistance gene from an Enterococcus faecium isolate of animal origin to an E-faecium isolate of human origin in the intestines of human volunteers. Antimicrob Agents Chemother. 2006;50(2): 596-9.

115. Bourgeois-Nicolaos N, Moubareck C, Mangeney N, Butel MJ, DoucetPopulaire F. Comparative study of vanA gene transfer from Enterococcus faecium to Enterococcus faecalis and to Enterococcus faecium in the intestine of mice. FEMS Microbiol Lett. 2006;254(1):27-33.

116. Launay A, Ballard SA, Johnson PDR, Grayson ML, Lambert T. Transfer of vancomycin resistance transposon Tn1549 from Clostridium symbiosum to 
Enterococcus spp. in the gut of gnotobiotic mice. Antimicrob Agents Chemother. 2006;50(3):1054-62.

117. Howden BP, Holt KE, Lam MMC, Seemann T, Ballard S, Coombs GW, Tong SYC, Grayson ML, Johnson PDR, Stinear TP. Genomic insights to control the emergence of vancomycin-resistant Enterococci. mBio. 2013;4(4):9.

118. Shoemaker NB, Wang GR, Salyers AA. Evidence for natural transfer of a tetracycline resistance gene between bacteria from the human colon and bacteria from the bovine rumen. Appl Environ Microbiol. 1992;58(4):1313-20.

119. Halula M, Macrina FL. Tn5030: a conjugative transposon conferring clindamycin resistance in Bacteroides species. Rev Infect Dis. 1990;12(Suppl 2):S235-42.

120. Bearson BL, Brunelle BW. Fluoroquinolone induction of phage-mediated gene transfer in multidrug-resistant Salmonella. Int J Antimicrob Agents. 2015;46(2):201-4.

121. Li J, Rettedal EA, van der Helm E, Ellabaan M, Panagiotou G, Sommer MOA Antibiotic treatment drives the diversification of the human gut Resistome. Genom Proteom Bioinf. 2019;17(1):39-51.

122. Peterson G, Kumar A, Gart E, Narayanan S. Catecholamines increase conjugative gene transfer between enteric bacteria. Microb Pathog. 2011; 51(1-2):1-8

123. Zeng XM, Lin J. Factors influencing horizontal gene transfer in the intestine. Anim Health Res Rev. 2017;18(2):153-9.

124. Jimenez AG, Sperandio V. Quorum sensing and the gut microbiome. London: Academic Press Ltd-Elsevier Science Ltd; 2019.

125. Galloway WR, Hodgkinson JT, Bowden SD, Welch M, Spring DR. Quorum sensing in gram-negative bacteria: small-molecule modulation of AHL and Al-2 quorum sensing pathways. Chem Rev. 2011;111(1):28-67.

126. Hudaiberdiev S, Choudhary KS, Vera Alvarez R, Gelencsér Z, Ligeti B, Lamba D, Pongor S. Census of solo LuxR genes in prokaryotic genomes. Front Cell Infect Microbiol. 2015;5:20.

127. Dyszel JL, Smith JN, Lucas DE, Soares JA, Swearingen MC, Vross MA, Young GM, Ahmer BM. Salmonella enterica serovar Typhimurium can detect acyl homoserine lactone production by Yersinia enterocolitica in mice. J Bacteriol. 2010;192(1):29-37.

128. McCuddin Z, Carlson SA, Rasmussen MA, Franklin SK. Klebsiella to Salmonella gene transfer within rumen protozoa: implications for antibiotic resistance and rumen defaunation. Vet Microbiol. 2006;114(3-4):275-84.

129. Ng KM, Ferreyra JA, Higginbottom SK, Lynch JB, Kashyap PC, Gopinath S, Naidu N, Choudhury B, Weimer BC, Monack DM, et al. Microbiota-liberated host sugars facilitate post-antibiotic expansion of enteric pathogens. Nature. 2013;502(7469):96

130. Jacobson A, Lam L, Rajendram M, Tamburini F, Honeycutt J, Pham T, Van Treuren W, Pruss K, Stabler SR, Lugo K, et al. A Gut Commensal-Produced Metabolite Mediates Colonization Resistance to Salmonella Infection. Cell Host Microbe. 2018;24(2):296.

131. Chow WL, Lee YK. Free fucose is a danger signal to human intestinal epithelial cells. Br J Nutr. 2008;99(3):449-54.

132. Pacheco AR, Curtis MM, Ritchie JM, Munera D, Waldor MK, Moreira CG, Sperandio V. Fucose sensing regulates bacterial intestinal colonization. Nature. 2012;492(7427):113.

133. Maier L, Vyas R, Cordova CD, Lindsay H, Schmidt TSB, Brugiroux S, Periaswamy B, Bauer R, Sturm A, Schreiber F, et al. Microbiota-derived hydrogen fuels Salmonella Typhimurium invasion of the gut ecosystem. Cell Host Microbe. 2013;14(6):641-51.

134. Lawhon SD, Maurer R, Suyemoto M, Altier C. Intestinal short-chain fatty acids alter Salmonella typhimurium invasion gene expression and virulence through BarA/SirA. Mol Microbiol. 2002:46(5):1451-64.

135. Van Immerseel F, De Buck J, Pasmans F, Velge P, Bottreau E, Fievez V, Haesebrouck F, Ducatelle R. Invasion of Salmonella enteritidis in avian intestinal epithelial cells in vitro is influenced by short-chain fatty acids. Int J Food Microbiol. 2003:85(3):237-48.

136. Peng MF, Reichmann G, Biswas D. Lactobacillus casei and its byproducts alter the virulence factors of foodborne bacterial pathogens. J Funct Food. 2015;15:418-28

137. Peng MF, Tabashsum Z, Patel P, Bernhardt C, Biswas D. Linoleic acids overproducing Lactobacillus casei limits growth, survival, and virulence of Salmonella Typhimurium and Enterohaemorrhagic Escherichia coli. Front Microbiol. 2018:9:14

138. Makras L, Triantafyllou V, Fayol-Messaoudi D, Adriany T, Zoumpopoulou G, Tsakalidou E, Servin A, De Vuyst L. Kinetic analysis of the antibacterial activity of probiotic lactobacilli towards Salmonella enterica serovar
Typhimurium reveals a role for lactic acid and other inhibitory compounds. Res Microbiol. 2006;157(3):241-7.

139. Bansal T, Alaniz RC, Wood TK, Jayaraman A. The bacterial signal indole increases epithelial-cell tight-junction resistance and attenuates indicators of inflammation. Proc Natl Acad Sci U S A. 2010;107(1):228-33.

140. Nikaido E, Giraud E, Baucheron S, Yamasaki S, Wiedemann A, Okamoto K, Takagi T, Yamaguchi A, Cloeckaert A, Nishino K. Effects of indole on drug resistance and virulence of Salmonella enterica serovar Typhimurium revealed by genome-wide analyses. Gut Pathog. 2012;4(1):5.

141. Curtis MM, Hu ZP, Klimko C, Narayanan S, Deberardinis R, Sperandio V. The gut commensal Bacteroides thetaiotaomicron exacerbates enteric infection through modification of the metabolic landscape. Cell Host Microbe. 2014; 16(6):759-69.

142. Takao M, Yen HL, Tobe T. LeuO enhances butyrate-induced virulence expression through a positive regulatory loop in enterohaemorrhagic Escherichia coli. Mol Microbiol. 2014;93(6):1302-13.

143. Zumbrun SD, Melton-Celsa AR, Smith MA, Gilbreath JJ, Merrell DS, O'Brien AD. Dietary choice affects Shiga toxin-producing Escherichia coli (STEC) 0157:H7 colonization and disease. Proc Natl Acad Sci U S A. 2013;110(23): E2126-33.

144. Hughes DT, Terekhova DA, Liou L, Hovde CJ, Sahl JW, Patankar AV, Gonzalez JE, Edrington TS, Rasko DA, Sperandio V. Chemical sensing in mammalian host-bacterial commensal associations. Proc Natl Acad Sci U S A. 2010; 107(21):9831-6.

145. Bachmann V, Kostiuk B, Unterweger D, Diaz-Satizabal L, Ogg S, Pukatzki S. Bile salts modulate the Mucin-activated type VI secretion system of pandemic Vibrio cholerae. Plos Neglect Trop Dis. 2015;9(8):22.

\section{Publisher's Note}

Springer Nature remains neutral with regard to jurisdictional claims in published maps and institutional affiliations.
Ready to submit your research? Choose BMC and benefit from:

- fast, convenient online submission

- thorough peer review by experienced researchers in your field

- rapid publication on acceptance

- support for research data, including large and complex data types

- gold Open Access which fosters wider collaboration and increased citations

- maximum visibility for your research: over $100 \mathrm{M}$ website views per year

At BMC, research is always in progress.

Learn more biomedcentral.com/submissions 